\title{
An assessment of the reading motivation skills of Nigerian primary school teachers: Implications for language and science education
}

\begin{tabular}{|c|c|}
\hline $\begin{array}{l}\text { Authors: } \\
\text { Foluso Okebu } \\
\text { Tunde Owola } \\
\text { Beatrice O.A. }\end{array}$ & $\begin{array}{l}\text { Kola }^{1} \\
\mathrm{i}^{2} \\
\text { Onafowokan }\end{array}$ \\
\hline \multicolumn{2}{|c|}{$\begin{array}{l}{ }^{1} \text { Department of Language, } \\
\text { Arts and Social Science } \\
\text { Education, Lagos State } \\
\text { University, Nigeria }\end{array}$} \\
\hline \multicolumn{2}{|c|}{$\begin{array}{l}{ }^{2} \text { Department of Science and } \\
\text { Technology Education, Lagos } \\
\text { State University, Nigeria }\end{array}$} \\
\hline \multicolumn{2}{|c|}{$\begin{array}{l}\text { Department, St. Augustine's } \\
\text { College of Education, Nigeria }\end{array}$} \\
\hline \multicolumn{2}{|c|}{$\begin{array}{l}\text { Correspondence to: } \\
\text { Beatrice Onafowokan }\end{array}$} \\
\hline \multicolumn{2}{|c|}{$\begin{array}{l}\text { Email: } \\
\text { bonafowokan@yahoo.com }\end{array}$} \\
\hline $\begin{array}{l}\text { Postal addres } \\
\text { PO Box 1254, } \\
\text { State, Nigeria }\end{array}$ & Ikorodu, Lagos \\
\hline \multicolumn{2}{|c|}{$\begin{array}{l}\text { Received: } 25 \text { Feb. } 2013 \\
\text { Accepted: } 18 \text { July } 2013 \\
\text { Published: } 03 \text { Sept. } 2013\end{array}$} \\
\hline \multicolumn{2}{|c|}{$\begin{array}{l}\text { How to cite this article: } \\
\text { Okebukola, F., Owolabi, } \\
\text { T. \& Onafowokan, B.O.A., } \\
\text { 2013, 'An assessment of the } \\
\text { reading motivation skills } \\
\text { of Nigerian primary school } \\
\text { teachers: Implications } \\
\text { for language and science } \\
\text { education', Reading \& } \\
\text { Writing 4(1), Art. \#33, } \\
12 \text { pages. http://dx.doi. } \\
\text { org/10.4102/rw.v4i1.33 }\end{array}$} \\
\hline \multicolumn{2}{|c|}{$\begin{array}{l}\text { (C) 2013. The Authors. } \\
\text { Licensee: AOSIS } \\
\text { OpenJournals. This wo } \\
\text { is licensed under the } \\
\text { Creative Commons } \\
\text { Attribution License. }\end{array}$} \\
\hline \multicolumn{2}{|l|}{ Read online: } \\
\hline 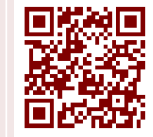 & $\begin{array}{l}\text { Scan this QR } \\
\text { code with your } \\
\text { smart phone or } \\
\text { mobile device } \\
\text { to read online. }\end{array}$ \\
\hline
\end{tabular}

Recent studies and frequent news reports have expressed concerns about African children's decreasing reading habits and dwindling achievement in language and primary science examinations. African children are not reading because they have reading difficulties or because they have no interest in books. This article focuses on the elementary schooling years, when the ability to read and comprehend and the love of reading are developed, using Nigeria as a case study. The article begins with a review of the literature on reading that underscores the importance of nurturing and supporting good reading habits amongst African children. Following a cursory exposition of the categories of schools in Nigeria and the place of reading and science in the National Policy on Education, the remainder of the article presents the findings of a study conducted to assess the reading motivation skills of primary school teachers and illustrates pedagogical ways of developing good reading habits amongst African children. Implications for language and science education are discussed.

\section{Introduction}

There is little debate amongst researchers, policymakers and educational stakeholders that reading achievement amongst African students is an important issue. There is also no contending the fact that improvement of literacy levels in schools throughout Africa poses a serious challenge requiring urgent intervention (Abel 2003; Bamhare 1999; Okebukola 2007; Warwick 1999). Onukaogu (2001) provides an excellent overview of the poor state of literacy in African schools. He identifies the following hindrances to the reading empowerment of the average African primary school child:

- Minimal experience of print immersion compared with children in the developed world.

- Lack of collaboration between the home, the community and the school in the provision of reading empowerment of the child.

- The current trend of having untrained and incompetent teachers in the teaching of reading in our schools.

Okebukola (2008) notes that most African elementary schools have no formalised reading programmes. Reading is subsumed in the English language lesson and taught by the language teacher. Thus, largely, reading is taught as a tool to reinforce other language skills rather than as a discipline. Warwick (1999), berating the worrisome situation, notes that African children lack opportunities for catching up to the rest of the world in terms of satisfying employment and political choices as a result of their low literacy levels and limited horizons. This situation may persist well into the 21st century, unless there are massive changes.

Several scholars have contributed greatly to the research literature on matters pertaining to African students and reading. Their recommendations are for better teachers, better textbooks, smaller classes, reformed curricula, better teacher remuneration, new political visions or changed attitudes (Abel 2003; Okebukola 2008; Warwick, 1999). As noted by Warwick (1999), all of these solutions have their place but most are impractical in the short run. They cost too much or they depend on social or political change, which will take generations to bring out. Africans need practical solutions and research continues to play a contributory role.

The discussion of the motivation skills of African primary school teachers and reading problems of students has also focused on the development of the English language as the national and educational language in most cases. This has been attributed to the lack of development of indigenous languages, which hardly ever have official or national functions. Thus, misgivings about students' level of proficiency in a medium of education other than their mother tongue have been internationally acknowledged (Mesthrie 2009). As noted by Okebukola (2012), this problem is carried over and persists even in higher education. Consequently, higher institutions across 
Africa prescribe courses in the medium of instruction for all students. For instance, in Nairobi and Addis Ababa, students are required to attend English proficiency classes. There is a communication skills centre at the University of Zimbabwe, a language and study skills unit at Nairobi University and a communication skills unit at the University of Dar es Salaam (Rugemalira 2007). In Nigeria, all higher institutions offer a General English course, a remedial programme to take care of deficiencies carried over from the lower levels of education.

Researchers have established links between the attitudes that children hold towards reading and the scores they obtain on reading tests (Gambrell, Hughes, Calvert, Malloy \& Igo 2011; Twist et al. 2007, cited in Okebukola 2012). They have long recognised that motivation is at the heart of many of the pervasive problems we face in teaching young children to read (Guthrie 1996; Okebukola 2005). Highly motivated readers are self-determining and generate their own reading opportunities. They want to read and choose to read for a wide range of personal reasons such as curiosity, involvement, social interchange and emotional satisfaction. According to Gambrell et al. (2011), students who are highly motivated to read will choose to read and continue to read over time. As noted by Bryne (2007), teachers are influential in motivating and improving attitudes towards reading. Children need support by their teachers to negotiate them away from potential points of discouragement in learning to read.

The International Reading Association (2000) reports that the teacher's knowledge makes a difference in student achievement. The teacher's role in the reading process is to create experiences and environments that introduce, nurture or extend students' abilities to engage with text. Recent studies on reading achievement show that children in the middle and upper primary schools hold less positive attitudes than previously towards reading. Also, fewer African children read for pleasure as a leisure activity outside of school (Arden 1999; Bamhare 1999; Warwick, 1999). Many researchers consider these developments alarming not only because of links between the attitudes that children in these levels of the primary school hold towards reading and the scores they obtain on reading tests, but also because the amount of time that teachers spend teaching reading at these levels at the primary school tends to drop off (Bruzo \& Flint 2007; McKenna \& Kear 1990).

Whether this decline in positive attitude towards reading found amongst African primary school children is caused by the lack of school time available to explore reading pleasure (Bruzo \& Flint 2007), lack of development of indigenous languages (Rugemalira 2007), poor knowledge of English from home (Okebukola 2012) or the effect of socio-economic status or incompetence of teachers (Onakaogu 2001) is worthy of consideration by educators. What can be said with certainty is that a multifarious layer of issues impinges on students' reading achievement and attitudes to reading in the middle and later years of primary school.
We concur with Lamont's (2007) call for further research in the middle and upper years of schooling so that we can better understand how to improve reading outcomes. Hence, to better understand the interweaving issues that could be the cause of this lack of progress, this study investigated the early literacy teachers' classrooms practices in Nigerian elementary schools to determine the extent to which they motivated their students to engage in reading and foster their students' attitudes towards improved achievement in reading.

We have focused on reading and primary science for several reasons. There is a meeting point between the medium of communication (English) and science (Achor 2003, cited in Owolabi \& Okebukola 2009). In all cases in which science is taught, teachers need to explain science concepts. As with any other subject, comprehension of science depends on the integration of appropriate ways of thinking, use of language and the appropriate degree of scaffolding by the teachers to support students' attainment of intended outcomes. All these have not been achieved with the traditional method (lecture) preponderantly employed by science teachers in Nigeria (Ajeyalemi 2002; Owolabi 2006). The state of primary science teaching has consistently been of concern because of the teachers' feelings of inadequacy in teaching science (Okebukola, Owolabi \& Okebukola 2013).

Many elementary teachers have poor attitudes and beliefs about science and their capacity to be effective teachers of science; hence, teachers doubt their ability to teach science effectively in classroom settings (Yore, Hildebrand, Osborne, Treagust \& Wallace 2004). The elementary school years are of considerable consequence for shaping mathematical, scientific and reading motivation and achievement (Okebukola \& Owolabi 2008). Children at this level experience learning far more with printed books for reading. It is within the formative years that children can be easily motivated to learn. Gomrell, Palmer, Codling and Mazzoni (1996) assert that children who are motivated and spend more time reading are better readers. Let us think back to our own elementary days and the changes in both reading ability and reading instruction as our grade level increased; if we look at how much we learned through reading in each grade, we realise that most reading instruction takes place in the early school years. At the secondary school level, instruction specifically related to reading tapers off, and more emphasis is placed on learning content in academic subject areas. It is therefore imperative to develop both the skill and the will to read for students to develop into mature and effective readers to be able to cope with advanced reading and scientific skills required at the secondary school level.

We consider that the qualitative research presented in this article is of particular relevance for the reflective professional in the classroom. We also note that the study reported here is part of a wider research project that is investigating the teaching of reading and reading achievement in Nigerian schools. As part of this main study, the researchers identified public schools as the ones not exhibiting an effective, regular 
and sustained approach to reading in English in the upper levels of the primary schools, against the dictates of the National Policy on Education (Makinde 2003; Okebukola 2005). Any discussion on reading in Nigeria must of course take recourse to the categories of schools and language provisions in the National Policy on Education. These are discussed in the following sections.

\section{Categories of schools in Nigeria}

There are generally two categories of schools in Nigeria: private schools and public schools. The basis for the difference is their types of ownership. Privately owned schools, according to Okebukola (2012), are those schools that are run and financed by individuals. They are completely autonomous and responsible for the day-to-day running of the schools' affairs, such as recruiting and laying off of staff, planning of the school's timetable, promotion of staff and studies, planning and conducting of examinations and admission of students. Private schools can also be owned by companies, churches, mosques, foreign embassies and universities. On the other hand, public schools are owned and financed by the state and federal government. The schools are run by agencies of the Ministry of Education, either at the state or federal government levels. These two categories of schools differ with respect to their governance and finance, formal structures, openness to change, quality of teaching staff and social relationships within them. These differences obviously have consequences on the output of the teachers and students.

\section{Language provisions in the National Policy on Education}

The policy on the use of language in Nigeria promotes multilingualism. English occupies a dominant position as the official language and in certification, since its imposition upon Nigerians by the colonial administration ordinances (Onukaogu 2006). In addition to English, Hausa, Igbo and Yoruba constitute the major Nigerian languages recognised by the National Policy on Education. Added to these is the
French language's ascendancy as the official language for smooth interaction with neighbours. The policy stipulates that in the first three years in the primary school (primaries 1-3), local languages are used as the language of instruction (LOI) whilst English is taught as a subject (ELT). In the remaining years of the child's education, that is from primary 4, English becomes the LOI and the local languages are taught as subjects (Federal Government of Nigeria 2004). However, as noted by Okebukola (2012), literacy implementation reports indicate flagrant deviation from the policy statements as many private primary schools adopt English as the LOI from pre-primary classes, in line with parents' preferences, whilst many public schools continue with local languages as LOI until the end of primary education as a result of pupils' poor backgrounds in English.

Comparative studies on reading performance of pupils in public and private schools reveal significant differences in favour of private schools and that reading achievement in public schools is very low (Federal Ministry of Education [FME] 2008; Okebukola 2007; Torahi 2000). The language provisions for each level of education can be seen in Table 1.

The magnitude of this problem causes not only innumerable personal tragedies but also significantly draws instruction down and jeopardises the future of our public schools. This is evident in the huge failure recorded by candidates who sat for the November/December 2009 National Examinations Council (NECO) Examination (a national examination conducted at the end of senior secondary school) in which only $1.8 \%$ passed (West African Examination Council 2010).

Nigerian youths fail examinations not only because they do not read their schoolbooks, but also because they lack mastery in reading as a result of the deficiency carried over from primary school. This is more pronounced in the sciences, largely due to the strong correlation between sound reading skills and the learning of science concepts. Researchers note that science texts are often more challenging for students because of the peculiar nature of science, which is not

TABLE 1: Language provisions in the national policy on education.

\begin{tabular}{|c|c|c|}
\hline Level of education & Education phase & Language provisions \\
\hline \multirow[t]{7}{*}{ Foundational education } & Pre-primary school & - Mother tongue (MT) or language immediate community (LIC) to be the medium of instruction \\
\hline & - & - Orthographies of many Nigerian languages (NLs) to be developed \\
\hline & - & - Textbooks in NLs to be produced \\
\hline & Primary school & - Language of environment (LIE) shall be the \\
\hline & - & - medium of instruction (first three years) \\
\hline & - & - English to be taught as a subject \\
\hline & - & - English shall progressively be used as a medium of instruction \\
\hline \multirow[t]{6}{*}{ Basic education } & - & - LIE and French to be taught as subjects \\
\hline & Junior secondary school & - LIC to be taught as language 1 \\
\hline & - & - One major Nigerian language other than that of \\
\hline & - & - the environment to be taught as language 2 \\
\hline & - & - English and French to be taught as subjects \\
\hline & - & - Arabic to be taught as a non-prevocational elective \\
\hline Senior education & Senior secondary school & - English and a major Nigerian language taught as core subjects \\
\hline
\end{tabular}

Source: Federal Government of Nigeria, 2004, National Policy on Education, Lagos 
narrative. Worse still, science teachers often lack the expertise and interest in teaching reading (Talanquer, Tomanek \& Novodvorsky 2013). It is desirable to expose science teachers to intricacies of reading in order to equip them with skills that will foster students' understanding of science and help them to become more proficient readers.

What is frustrating is that most reading failure can be prevented if teachers apply what is known about early reading instruction, reading improvement and remediation (Okebukola 2007). For example, researchers and reading experts have sensitised us to the fact that reading instruction is not limited to teaching important skills. It is not just a cognitive process; it is also an affective process (Madden 1988; Oldfather 1993). Affective aspects of the reading process include a reader's general attitude towards and interest in reading. These play an important role in the way readers approach reading experiences and in the way they respond to them. For example, a child who views reading as a boring activity is not likely to respond very well to an opportunity to read. Moreover, this child will not comprehend or respond to a passage as well as someone who views reading as an exciting activity and becomes engaged in almost any reading experience. All readers comprehend and respond better when they are interested in reading. In the light of this, McLaughlin (2012) proposes that the affective aspects of reading be advocated and promoted as a reformed framework for the teaching and reading in Africa, especially in light of an acceptance of reading as an interaction between the teacher, text and the reader.

The interactive explanation of how a person reads and develops interest in reading presents a holistic approach to the teaching of reading. It integrates the engagement perspective with cognitive, affective and other social aspects of reading. Engaged learners achieve because they want to understand. They possess intrinsic motivation for interacting with text. They use cognitive skills to understand and they have positive attitudes about reading (McLaughlin 2012). It assumes that:

1. Meaning is located both within the text and in the meaning that readers bring to the text.

2. Reading consists of both translation and expectation.

3. Reading proceeds as each knowledge source interacts simultaneously with the print on the page and with other knowledge sources: vocabulary, syntax, discourse and metacognition within a socio-cultural environment.

This is represented as a Venn diagram in Figure 1.

It is against this background that the case study that follows assesses the frequency with which elementary school teachers engage their pupils in activities that are supported by research as being capable of developing interest and attitudes that increase motivation and facilitate comprehension and response (Fletcher, Grimley, Greenwood \& Parkhill 2012; Madden 1988; Okebukola 2007; Oldfather 1993).

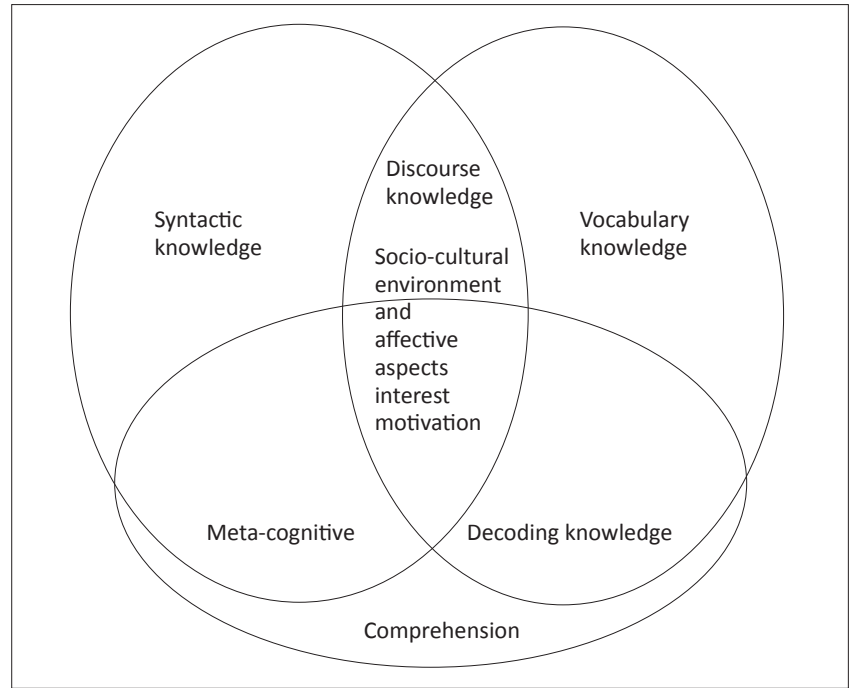

FIGURE 1: Interactive model of the reading process.

\section{Methodology}

Our research methodology was underpinned by Ford's (1992) motivation systems theory, which maintains that people will attempt to attain goals they value and perceive as achievable. Bryne (2007) identifies the environment and the information available to the learner through the teacher as the major pillars of success in learning to read. Thus, our present study focuses on what teachers are doing in the classroom to develop and motivate reading. We were intent, throughout our data collection and analysis, on exploring the extent to which teachers' practices could impact on pupils' reading interest.

\section{Research design}

The study employed a descriptive survey design to unveil the frequency with which teachers incorporate activities that have been found to influence reading interest and achievement positively (Fletcher et al. 2012; Madden 1988; Palinscar \& Ransom 1988). A self-developed questionnaire titled 'Activities for Promoting Reading Interest Achievement' (APRIA) was used to collect data. The APRIA consisted of eight items designed to elicit indices of reading interest, such as: reading to children, guiding children to read, storytelling, identifying children's attitude to reading, picture reading, book talks, using questions and reading remediation. The indices were measured on a four-point scale of very often, often, rarely and never.

This instrument was validated by subjecting the items to critical review by two experts in language education with specialisation in reading and two experts in primary science. The instrument was further subjected to a pilot study in order to identify items that might be misconstrued by the teachers. A Cronbach alpha method of establishing reliability was used and a value of 0.81 was obtained.

\section{Project participants}

We developed a set of guiding principles developed keeping in mind sociocultural theory as set out in work by Vygotsky 
(1978), which emphasises the socially constructed nature of learning. Students learn through experiences that have authenticity and meaning for them, especially with respect to their social, economic and cultural backgrounds and through interactions with others (Cullen 2002). The selection criteria include the following:

- All the schools were public in ownership.

- All the teachers were professionally trained. They demonstrated low expectations of students but believed that teachers can improve achievement in reading.

- Pupils were from low socio-economic backgrounds and speak the local language at home.

Our conclusions were confirmed by research reports (FME 2008; Makinde 2003; Okebukola 2012; Okebukola \& Apari 2012). Also, the assessment records and classroom observations provided evidence of the overall poor reading achievement of the pupils in the schools. A self-developed observation protocol titled 'Primary Science Observation Schedule' (PSOS) was used to gather data on classroom interaction. The PSOS is divided into three components: teaching initiated by the teacher, teaching initiated by students and teacher and student involvement in experimental work. Each component is sub-divided into questioning, inquiry, discussion and activities. These components are distributed across the 30-minute duration of a science class. Teacherstudent interactions were recorded by observers with a tick in the appropriate cell to indicate an occurrence of a behaviour. No behaviour was recorded more than once within a minute.

The four schools selected are situated in urban and rural areas in four educational districts of Lagos State. A sample of 12 teachers was drawn from this population. These consisted of one teacher from primaries 4, 5 and 6 from each school. They are generalist teachers (teach all subjects) and have taught for at least 20 years. All the teachers were professionally trained and possess a Bachelor of Education (B.A. Ed. or B.Ed.) and National Certificate in Education, which is the minimum qualification for teaching at the primary school level. They have regular reading programmes as prescribed by the primary English language curriculum. Their ages range between 21 and 60.

Classes varied in size. At the time of the study, the smallest class had 61 pupils; the largest had 119. Each class was managed by one teacher. The ethnic composition within the classes differed, with Yoruba pupils as the dominant ethnicity. The proportions of Yoruba pupils across the four schools ranged from $60 \%$ to $96 \%$. The other two main ethnic groups were Igbo and Hausa: $2 \%-29 \%$ and $0 \%-10 \%$ respectively. All the pupils speak Yoruba, the language of the environment.

\section{Data collection}

Data collection and analysis were done using the case study method. This allowed us to explore the interweaving and complex aspects and conditions involved in improving reading literacy pedagogy (Fletcher et al. 2012). At each school, the head teacher identified and asked exemplary teachers of English language in years 4-6 to participate in the study. 12 teachers participated and we interviewed each of them individually. Each semi-structured interview took approximately 45 minutes. The questions we asked included the following:

- How important do you consider motivating children to read at this level?

- What is your perception of your pupils' attitude to reading?

- How do you measure this?

- What methods do you use in teaching reading?

- What are the barriers to the teaching of reading at this level and in this type of school?

- How do you use book talks to promote reading?

- What remediation strategies do you use for ineffective readers?

- How do you use picture books to promote reading?

- Apart from the items listed in the questionnaire, what other activities do you use in promoting reading?

We also carried out classroom observations of each teacher teaching reading. Each observed lesson was approximately 40 minutes in duration. We viewed the interview data as data reflecting a reality jointly constructed by interviewer and participant and acknowledged by both as being contextually situated (Rapley 2007). The classroom observations helped us to form an even deeper understanding of individual contexts. The items on the questionnaires were then discussed in depth with the teachers to control any confounding variables that could interfere with the actual outcome of the study. Frequency of occurrence of each variable was obtained using a 4-point Likert scale: very often, often, rarely and never, converted to points 3, 2, 1 and 0 . Parametric statistics of mean and mean-rank were computed.

\section{Data analysis}

The triangulation method was employed to establish the general order of rating teachers' frequency of use of the reading

TABLE 2: Profiles of the participants.

\begin{tabular}{|c|c|c|c|c|c|c|c|c|}
\hline School & $\begin{array}{l}\text { School } \\
\text { type }\end{array}$ & Age range (Pry 4) & Age range (Pry 5) & Age range (Pry 6) & $\begin{array}{l}\text { Ethnic } \\
\text { mix }\end{array}$ & $\begin{array}{l}\text { Confinement } \\
\text { area }\end{array}$ & $\begin{array}{l}\text { Number of students } \\
\text { in class (range) }\end{array}$ & $\begin{array}{l}\text { Number of teachers } \\
\text { interviewed }\end{array}$ \\
\hline A & Public & $8-12$ & $10-12$ & $11-15$ & $\begin{array}{l}\text { Mostly Yoruba } \\
\text { with } 40 \% \text { others }\end{array}$ & Urban & $40-80$ & 3 (1 at each level) \\
\hline B & Public & $8-12$ & $10-12$ & $11-15$ & $\begin{array}{l}\text { Mostly Yoruba } \\
\text { with } 45 \% \text { others }\end{array}$ & Urban & $50-75$ & 3 (1 at each level) \\
\hline C & Public & $8-12$ & $10-12$ & $11-15$ & $\begin{array}{l}\text { Mostly Yoruba } \\
\text { with } 20 \% \text { others }\end{array}$ & Rural & $50-100$ & 3 (1 at each level) \\
\hline D & Public & $8-12$ & $10-12$ & $11-15$ & $\begin{array}{l}\text { Mostly Yoruba } \\
\text { with } 27 \% \text { others }\end{array}$ & Rural & $60-120$ & 3 (1 at each level) \\
\hline
\end{tabular}

Pry, primary. 
interest-promoting activities. Interview and observation data were subjected to open coding to draw out the themes as they relate to our primary research question (what the teachers were doing to promote reading interest in their children). This is to establish connections and differences between both data sets (Gambrell et al. 2011; Strauss \& Sawyer 1986).

Table 3 shows the ordinal rating of the frequency of teachers' use of activities that promote reading interest amongst primary 4 students. Reading aloud to children had the highest ranking (mean $=3.40$ ), closely followed by identifying children's attitude to reading (3.20) and using questions (3.20). Storytelling ranked fourth with a mean of 3.0, whilst talking about books ranked fifth (mean $=2.20$ ). Reading picture books and reading remediation did not enjoy the teachers' patronage $($ mean $=0)$.

Table 4 shows the ordinal rating of the frequency of teachers' use of activities that promote reading interest amongst primary 5 students. Reading aloud to children had the highest ranking (mean $=3.20)$, closely followed by identifying children's attitude to reading and using questions (3.00). Storytelling ranked fourth with a mean of 2.88, whilst talking about books ranked fifth (mean $=2.20$ ). Reading picture books and reading remediation did not enjoy the teachers' patronage $($ mean $=0)$.

TABLE 3: Mean and mean rank of primary 4 teachers' frequency of use of reading interest activities.

\begin{tabular}{llll}
\hline Item number & Item statement & Mean & Mean rank \\
\hline 1 & Reading aloud to children & 3.40 & 1 \\
3 & Identifying children's attitude to reading & 3.20 & 2 \\
5 & Using questions & 3.20 & 2 \\
6 & Storytelling & 3.0 & 4 \\
4 & Talking about books & 2.20 & 5 \\
7 & Guided reading & 0 & 6 \\
8 & Reading remediation & 0 & 6 \\
\hline
\end{tabular}

TABLE 4: Mean and mean rank of primary 5 teachers' frequency of use of reading interest activities.

\begin{tabular}{llll}
\hline Item number & Item statement & Mean & Mean rank \\
\hline 1 & Reading aloud to children & 3.20 & 1 \\
4 & Identifying children's attitude to reading & 3.00 & 2 \\
6 & Using questions & 3.20 & 2 \\
7 & Storytelling & 2.88 & 4 \\
5 & Talking about books & 2.20 & 5 \\
8 & Reading picture books & 0 & 6 \\
2 & Guided reading & 0 & 6 \\
3 & Reading remediation & 0 & 6 \\
\hline
\end{tabular}

TABLE 5: Mean and mean rank of primary 6 teachers' frequency of use of reading interest activities.

\begin{tabular}{llll}
\hline Item number & Item statement & Mean & Mean rank \\
\hline 1 & Reading aloud to children & 3.60 & 1 \\
4 & Identifying children's attitude to reading & 3.50 & 2 \\
6 & Using questions & 3.50 & 2 \\
7 & Storytelling & 3.0 & 4 \\
5 & Talking about books & 2.20 & 5 \\
8 & Reading picture books & 0 & 6 \\
2 & Guided reading & 0 & 6 \\
\hline
\end{tabular}

Table 5 shows the ordinal rating of the frequency of teachers' use of activities that promote reading interest amongst primary 6 students. Reading aloud to children had the highest ranking (mean $=3.60$ ), closely followed by identifying children's attitude to reading and using questions (3.50). Storytelling ranked fourth with a mean of 3.0, whilst talking about books ranked fifth (mean $=2.20$ ). Reading picture books and reading remediation did not enjoy the teachers' patronage $($ mean $=0)$.

\section{Findings}

The findings of the study across the four schools and the 12 teachers sampled are hereby presented in line with the item statements.

\section{Reading aloud to children}

The teachers rated reading aloud to children highest of the activities used in promoting reading interest (primary 4 mean $=3.40$; primary 5 mean $=3.20$ and primary 6 mean $=3.60)$. Classroom observations and the scheduled interviews revealed that a popular and consistent part of the daily reading programme in the case study schools was for the teacher to read aloud to the whole class (model reading). Then the children read aloud, after which the teacher asks questions on the selection from the graded basal reader.

\section{Guiding children to read}

None of the teachers used guided reading in their classrooms. In fact, they were ignorant of this as a separate reading strategy, equating it with reading aloud. The researchers educated them and sought their views on their adoption of its use. Their only concern was practicability given the largeness of the classes.

\section{Identifying children's attitude to reading}

The teachers rated their frequency of identifying children's attitude to reading high (mean $=3.20)$, second in ranking in all three grades along with the use of questions. They berated children's poor attitude to reading and preference for television, soccer and video and noted that this has culminated in their poor performances in examinations. They were, however, unaware of techniques that can be used in measuring attitude to reading.

\section{Book talks}

Some of the teachers in the study engaged the children in book talks, but this was limited to the basal readers used in class. They only talked about the stories in the passages read in class.

\section{Using questions}

Questioning occurs frequently during the teachers' classroom reading lessons. This was rated high (means $=3.20$ across grades), second in the ranking. The basal readers used by the sampled teachers have questions that follow the reading 
material, with the result that the children have to re-read the material before being able to answer the questions. Classroom observations reveal that the teachers use questions largely to test, not teach reading comprehension. In such reading tests we find unsatisfactory instructions, such as 'Read the following passage and answer the questions below'. Often the child's approach to this task is to read the questions first. The validity of such reading comprehension tests is very questionable.

\section{Storytelling}

Storytelling ranks fourth (means of 3.0 in primary $4 ; 2.88$ in primary 5 and 3.0 in primary 6 ). The interview sessions revealed that the stories were limited to those in the basal reader passages during reading lessons. According to the teachers, storytelling only features in the English language curriculum of the lower primary classes (1-3).

\section{Reading picture books}

None of the teachers used picture books to encourage and motivate their pupils to read. Even though the basal readers contained illustrations of the stories in the reading passages, teachers did not spend time exploring the pictures and relating them to the text. The teachers, upon further probe into why they did not read and discuss the pictures with their pupils, noted that they thought the pictures were for aesthetic purposes.

\section{Motivating reading}

All the sampled teachers agreed that motivating children to read is their primary responsibility, but conceded that they were less prepared to teach reading beyond the use of basal readers.

\section{Discussion}

The concern of this study was to assess the motivation skills of Nigerian public primary school teachers. How frequently do they use the tried and tested activities for promoting interest in and positive attitudes towards reading? What difficulties do they encounter in teaching the children to read? The findings reveal some consistency in teachers' practices across the grades studied (primary grades 4-6). They appear to indicate that Nigerian primary school teachers adopt the basal reader approach through graded series, as earlier observed by Abel (2003) and Onukaogu (2001). In the process, they use reading aloud to children as the major activity that guides instruction. This focuses on oral decoding and the development of comprehension through assessment practice. Previous research supports the notion that teachers can motivate interest in reading amongst primary school children if they read aloud to them (Fletcher et al. 2012; Lynch-Brown \& Tomlinson 2010).

However, reading aloud using the basal reader approach as practised by the teachers follows the pattern of teacher 'reading' and students 'chorusing' from the prescribed textbook. They are thus made to learn reading by rote memorisation. The resultant effect is their inability to recognise or read unfamiliar words. Although a few brilliant students pick up reading by this laborious method, the majority of them end up as non-readers. Teachers focus attention on the negligibly few readers in reading classes whilst the non-readers, who form the bulk of the class, are left in limbo (Okebukola 2005). These teachers based their success in increasing motivation through the reading aloud on the fact that some of the students can read. Teachers displayed ignorance of the use of guided reading even though research is replete with evidence of the benefits of guided reading in promoting reading and enhancing comprehension (McLaughlin 2012).

In guided reading, the teacher divides the class into small groups and provides support as they learn to use various reading strategies (context clues, letter and sound relationships, word structure and so on). The teacher observes the students as they read the text silently to themselves. The teacher provides guidance and coaching to individuals based on their observations, providing prompts, asking questions and encouraging attempts at reading strategy application. Guided reading models are available on YouTube.

The finding that teachers are unaware of techniques to measure attitude to reading is supported by Elley (1989), who notes that children's attitude to reading has been ignored because the affective aspects of reading tend to be ill-defined and to involve shadowy variables difficult to conceptualise, measure and address instructionally. The importance of attitude in reading efficiency is widely recognised. Anderson, Hiebert, Scott and Wilkinson (1985) note that becoming a skilled reader requires learning that written material can be interesting. The emotional response to reading is the primary reason most readers read and probably the primary reason most non-readers do not read (Smith 1988). This underscores the important role played by children's attitudes in the process of becoming literate and the need for teachers to provide adequate motivation on the part of the learner.

Book talks are limited to stories in the passages read in class as result of the low socio-economic status of the parents, which prevents them from buying books, including the prescribed basal readers. Evans (2009) notes that it is not enough to just read a book; one must talk about it as well. Children's experience needs to be mediated by sensitive talk with more experienced readers. This may require that teachers periodically introduce new books to the children. As they do this, they talk about the book being introduced as if trying to 'sell' it to the children. They can talk about the title, the author, the general plot of the story and mention something special about the book or author that will interest the students to read the book. Children should also talk about the books they have read. Fletcher et al. (2012) report that book talks fostered interest and promoted motivation to read for enjoyment amongst primary school students.

The use of questions to test rather than teach reading, as observed in this study, renders the validity of such reading tests questionable; they fail to recognise that we read 
differently for different purposes, they do not promote reflective thinking and they place the teacher in a director's role. This diminishes the conversational nature of interaction.

Research supports that questioning aids comprehension, but it has to be used prudently to serve the various purposes. Kleuseus and Griffith (1996) suggest the following question types, which have been tried and tested in their own studies:

1. Metacognitive process questions, which help children get in touch with their own abilities to construct meaning. An example is: 'Why do you think eggs might hatch?'

2. Conversational questions, which are used to draw children into a conversation about a concept. An example is: 'Mary, what do you see in the picture?'

3. Discussion questions, which help to expand meaning through explanation, demonstration and sharing of related experiences and enable assessment of the children's knowledge. An example is: 'How does one snore?'

4. Prediction questions help to generate conversation and to model how readers use information from past experiences to make inferences about a new topic. An example is: 'What would have happened if Alice in her experience in Wonderland could not get smaller after entering the garden?'

The fact that the sampled teachers do not engage in storytelling, because it features in the curriculum only in lower classes, attests to the fact that public school teachers use the curriculum rigidly as a recipient rather than using it as a launch pad to teaching and learning (Okebukola 2012). Research indicates that storytelling has a positive impact on students' attitude to reading and develops and improves their thought processes and social interactions (Ryan 2012). Enjoying stories gives a shape to listening to stories read, and to reading and writing your own stories (Clay 1991). Storytelling is a great passion for children. In fact, it is universal for all human beings, regardless of culture. As noted by Evans (1998) and Gambrell (2011), its origins stretch back tens of thousands of years to when human beings were hunters and told stories to explain the mysteries of life in the world around them: where we go, when we die, why the sun rises and falls, when there is winter, the wisdom of animals, and so on. Storytelling has served the human race for the preservation of knowledge, wisdom and entertainment from the moonlight tales to the printing press, cinema, television and the Internet - all means of sharing and enjoying stories. All of us have fond memories of stories as told by parents and guardians 'around the fire' or teachers in the elementary classes who have harnessed the benefits within the structure of their everyday teaching roles.

Teachers' ignorance of the use of picture reading as a motivating strategy is a reflection of deficient training. Research provides evidence that picture reading plays an important role in the development of reading for all children (Fletcher et al. 2012; Morrow 1988). Picture books provide a powerful and reflective way of arousing and maintaining the children's interest in reading when they are selected with care to capture their interest and imagination. The books should be sophisticated in terms of narrative, illustration and design and should have storylines of high interest to children (Fletcher et al. 2012).

Different scenarios in the children's environment can provide hints for picture reading, such as illustrations of farmers harvesting crops, market scenes, motor parks, voting during elections, mountains, village life and so on. Probing questions (Who? How? Why? Where? Who are these people? Where are they going? Why do you think that woman is sitting down? etc.) can provide a useful guide for the reader's perceptions of the written story as the teacher encourages the students to engage in critical discussions and debate and to listen to and respect others' views. Arizpe and Styles (2003) note that sometimes just reading and talking about a picture book can be enough. But teachers always look for sympathetic ways of extending children's responses. Activities preceding, accompanying or following reading should help children to explore the themes and meanings in pictures.

Reading remediation poses another challenge to the sampled reading teachers. The teachers' responses to the question of remediation strategies to help ineffective and reluctant readers reveal that they realise that the majority of their students are non-readers, but are ignorant of the remediation strategies to use. The basal reader approach has come to be accepted as the norm rather than the exception. Many of these teachers rely on this approach, being the avenue through which they were taught themselves, even though they are not oblivious to the fact the that majority of their classmates dropped out of school as a result of their inability to rise above reading mediocrity due to the ineffectiveness of their teachers and their methods.

In their synthesis of research in early reading, Simmons and Kame'enui (1998) identified foundational concepts on big ideas that were common to all theoretical models of reading acquisition and were consistent across the architecture of effective reading interventions that every teacher must know. They serve as the framework for emergent reading instruction (Okebukola 2005). These concepts are: phonological awareness, alphabetic understanding and automaticity with code. Teachers must also be equipped with the modalities and basic steps in reading development and remediation. These steps are: note the problem, teach the basic techniques, practise, verify your success and build on your success.

Children come to school from different language groups, different cultures, different socio-economic status and different backdrops that affect their learning. One of these is the home. Some children grow up in homes where cuddles and storybooks are a nightly ritual, reading for them starts at home as parents or siblings share the joy of reading with them. For those who come from a non-reading culture home, as is the case with many African children, it is the teachers who bear the responsibility of luring them into the wonderful world of the written word. Schools have to teach 
children, whether they come from literate homes or not. Unfortunately, in many cases, as was the case in the rural and urban public schools in this study, these two groups of children are thrust into a literacy curriculum that is more appropriate for children from literate homes. The curriculum mismatch may prove detrimental for many children because it places them at risk of not learning to read and to write. This calls for professional resourcefulness on the part of the teacher to provide the necessary scaffolding to bridge the gap between the two groups.

Many literate parents take advantage of the schoolparent partnership programmes that feature guidelines to conducting formal, school-like activities in the home, such as storybooks, reading and homework assignments. Research supports a strong link between parents' reading to and with the children and children's literacy learning (Morrow 1993). However, non-literate parents may not know how to involve their children in these functional literacy activities. This further jeopardises the reading efficiency of their children. The teachers then need to provide remediation support for such children.

Teachers in this study were not prepared to teach reading beyond the use of basal readers. To them, reading instruction is synonymous with the application of the pre-packaged commercial graded reading books. They are unable to question the prescribed textbooks they are required to use or to maintain any autonomy in what and how to teach the children in order to ensure positive outcomes because of their limited exposure and training. Of more serious concern to the teachers is their inability to deal with the appalling poverty level of children enrolled in public schools compared with their counterparts in private schools, with the attendant benefits of adequate care, good food and rich literacy practices (Okebukola 2012).

Without exception, teachers felt that poverty was the source of most of the children's problems: 'Many of them come to school on empty stomachs'; 'Many of them sleep during classes;. The majority of them do not have textbooks or writing materials: 'They hawk different types of things after school hours so they cannot afford to attend remedial classes even if provided free by teachers'. Many have health challenges resulting from malnutrition. One teacher lamented: 'We have a difficult task in our hands: how do we teach an hungry and angry child to read?' To the teachers, therefore, motivation to read is least on the list of many of the children's problems. There is a substantial body of research that suggests that poverty and low academic achievement are causally related (Okebukola 2012; Simmons \& Kame'enui 1998). Cunningham Zibulsky and Callan (2009) found that poverty is the largest correlate of reading achievement.

\section{Implications for language and science education}

A decline in motivation to read can have deleterious effects on the acquisition of reading achievement and comprehension, not only in language in classrooms but also in content area instruction, especially the sciences. Most elementary science teachers would agree that a central purpose of their instruction is to help students to understand significant science concepts. Even though science teachers may not be language teachers, reading specialists or librarians, every science teacher knows that their subject is different from any other and requires particular kinds of literary skills. Hence, every science teacher must carefully consider how to use reading in their subject area because understanding subject matter involves more than 'doing' or 'knowing' something. Mastery of content is demonstrated not only through experimentation but also through reading (Owolabi \& Okebukola 2009).

Research has provided evidence that reading informational science texts can help to support content learning (Mantzicopoulos \& Patrick 2010; Okebukola \& Onafowokan 2003). Exposure to informational texts in the early years presents a vital means of expression of thought, especially in this modern world of science and technology which demands that one should be able to take an intelligent and informed interest in happenings within one's environment and the world at large (Okebukola 2005). Every field of specialisation has its own appropriate technical vocabulary. Science is no exception; informational science textbooks contain technical vocabulary, which children must learn and use for discourse in science. Several observations and studies regarding the Nigerian Educational System and language problems have revealed that the linguistic discontinuity that exists between the language of the home and the language of the school is a great handicap in the use of English, as noted by Okebukola \& Owolabi (2008).

The vocabularies of most school certificate candidates are not rich. This is inescapable because of the danger of loss in vocabulary concomitant with change from one language to another, especially with the shift from the mother tongue to English at the upper primary level (FME 2008). The following examples from students' scripts illustrate this point:

1. 'The changes are that during the windy or dry season, all the leaves will dry away from the tree and in the raining season, the new beautiful leaves will grow.'

2. 'When male and female toad make love ...' (WAEC 2004)

In sentence (1) the student probably had in mind the trees shedding their leaves whilst in sentence (2) the word copulate was intended.

Reading informational science texts aloud to children exposes students to specialised vocabulary (Duke \& Kays 1998), prompts discussion on science topics and promotes scientific thinking (Okebukola \& Onafowokan 2003; Smolkin \& Donovan 2002). Despite compelling reasons for sharing informational text with young children, considerable evidence has accrued over the past decade that children have limited exposure to this type of text (Yopp \& Yopp 2012).

The importance of language within science education has been demonstrated by Okebukola and Owolabi (2008), who found that classroom activities that promote the use of 
'analogies' improve children's ability to use language as a tool for both individual and collective reasoning. Classroom discussion using reading aloud has also been found to foster achievement in science (Okebukola 1999). By the same token, engaging students in question-and-answer relationships activates their prior knowledge, prompts them to connect ideas and encourages them to restructure their thinking (Okebukola \& Owolabi 2007).

A growing number of educators recognise the key role of language in science learning. Science vocabulary can be daunting for students, particularly for those with low literacy. Such words as 'metamorphosis', 'esterification' and 'effervescence' are often difficult for students to comprehend. There is increasing awareness of and moves to enhance the interaction between the literacy and science educators (Yore et al. 2004). Every science teacher should therefore also be a teacher of literacy. Researchers and educationists acknowledge that the students' attitude towards reading is a central factor affecting reading performance in the languages and in the sciences. These conclusions are based on a long history of research in which attitude and achievement have consistently linked (McKenna \& Kear 1990).

\section{Recommendation}

The affective aspects of the reading process - interest, attitude and motivation - are at the very heart of reading. They undoubtedly have some correlation with reading efficiency. As noted earlier, the teachers in this study were actively aware of the critical role they should play in supporting deficient readers, but they lacked the ability. This provides further evidence that teachers need help urgently in the understanding of what reading is, how children learn how to read and what they need when learning to read.

African governments should begin to think of ways to integrate new literacies into the literacy programmes of schools. They should focus on the professional development of teachers and plan the teacher education curriculum around the classroom needs of the teachers. The reading curriculum must help teachers to develop an informed understanding of the relationship between policy, research and practice.

Teacher education programmes should include the procedure for using reading aloud and the selection of information texts. The school libraries should be stocked with science informational books in addition to the recommended textbooks. These include periodicals, Internet-based texts, newspapers and magazines. These should be shared aloud with children with explanation of content, text structures and language. Students' engagement in discussions, making connections between content of the selection and children's lives, classroom experiences and the curriculum will make the text more meaningful (Yopp \& Yopp 2012).

Any government intervention should also aim at closing the achievement gap between public and private primary school children, improving the quality of the teachers, cushioning the impact of poverty amongst the children in the short term and eradicating poverty amongst the citizenry in the long term. The means to this end should include a complete overhaul of the teacher education programmes at all levels to include competency-based reading curricula with the recognition of reading as a subject on the timetable.

One way by which these teachers can promote independent reading is through classroom lending libraries. They can establish this through the support of the Parent-Teacher Association (PTA) by educating and raising the awareness of parents on the benefits of giving their children access to a variety of books that they can read at home. This also serves to foster home-school connections. This idea was suggested by the researchers, but teachers informed us that such associations only thrive in private schools, attended by children from rich homes.

Government and non-governmental organisations (NGOs) can organise television shows that promote the love of reading. Since the youths show interest in television, soccer, music, videos, movies, clubbing, fashion and Internet social networks, reading programmes should incorporate all of these to sustain their interest. Local councils, NGOs and corporate bodies, especially reading associations, can organise book clubs where children can engage in interestgenerating activities such as discussions on similarities between books and movies, read aloud sessions, gift of books, literacy fairs, incentives and rewards, scholarships, sharing reading experiences, visits to the library, awards for children writers and exposure to children's literature.

\section{Conclusion}

The analysis presented in this article demonstrates that the basal reader alone is not enough for teaching reading. A new type of intervention is needed: one taking a multisectional approach. The activities discussed could prove to be innovative and successful initiatives in early and developmental reading. The variety of interventions develops practical activities in the effective domain, which have been found to improve reading competence in mainstream classrooms internationally. It makes no sense to force children to read. It is better to attract them, arouse their interest and make them see that real success comes from reading and that reading can be fun. Definitely, there must be a way to change future of our children. They must read because the secrets to survival are hidden in books.

\section{Acknowledgments Competing interest}

The authors declare that they have no financial or personal relationship(s) that may have inappropriately influenced them in writing this article.

\section{Authors' contributions}

F.O. (Lagos State University) was the lead researcher and the main writer. T.O. (Lagos State University) was researcher and responsible for computation of the data, whilst B.O.A.O. (St. Augustine College of Education) was an assistant 
researcher in charge of data collection, administrative work and publication.

\section{References}

Abel, L., 2003, 'Challenges of reading teachers in multilingual settings in South Africa', in A.E Arua (ed.), Reading For All In Africa, pp. 18-37, International Reading Association, Newark, DE.

Ajeyalemi, D., 2002, 'Capacity building in the sciences: Imperatives for teacher education in Nigeria', Inaugural Lecture Series, University of Lagos Press, Lagos.

Anderson, R.C., Hiebert, E.H., Scott, J.A. \& Wilkinson, I.A., 1985, Becoming a Nation of Readers: The Report of the Commission on Reading, National Institute of Education, Washington, DC.

Arden, R., 1999, 'Strengthening school-based staff development structures to support language proficiency in the classroom: A DFID perspective on Botswana, Lesotho, Namibia and Swaziland', in S. Monaka (ed.), Reading For All In Africa, pp. 91-94, International Reading Association, Newark, DE.

Arizpe, E. \& Styles, M., 2003, Children Reading Pictures, Routledge Falmer, London.

Bamhare, M., 1999, 'The children's reading ten project: A 2BBC "Reading for All" strategy', in S. Monaka (ed.), Reading For All In Africa, pp. 104-109, International Reading Association, Newark, DE.

Bruzo, W. \& Flint, E., 2007, 'Content literacy: Fundamental toolkit elements', Reading Teacher 61(2), 192-194. http://dx.doi.org/10.1598/RT.61.2.9

Bryne, B., 2007, 'Theories of learning to read', in M.J. Snowling \& C. Itulme (eds.), The Science of Reading: A Handbook, pp. 104-119, Blackwall, Molden, MA.

Clay, M., 1991, Becoming literate: The construction of inner control, Heinemann, Portsmouth, $\mathrm{NH}$.

Cullen, J., 2002, 'The social and cultural contexts of early literacy: Making the links between homes, centres and schools', in P. Adams \& H. Ryan (eds.), Learning to read in New Zealand. A collaboration between Early Childhood Education, Families and Schools, pp. 47-51, Dunmore, Palmerston North

Cunningham, A.E., Zibulsky, J. \& Callan, M.D., 2009, 'Starting small: Building preschool teacher knowledge that supports early literacy development', Read Writ 22, 487510. http://dx.doi.org/10.1007/s11145-009-9164-z

Duke, N.K. \& Kays, J., 1998, “"Can I say once upon a time?" Kindergarten children developing knowledge of information book language', Early Childhood Research Quarterly 12(2), 299-318.

Elley, W.B., 1989, 'Vocabulary acquisition from listening to stories', Reading Research Quarterly 24, 174-187. http://dx.doi.org/10.2307/747863

Evans, J., 1998, 'Responding to illustrations in picture story books', Reading 32(2), 27-32. http://dx.doi.org/10.1111/1467-9345.00086

Evans, M., 2009, Foreign language learning with digital technology, Continuum, London.

Federal Government of Nigeria, 2004, National Policy on Education, Lagos.

Federal Ministry of Education (FME), 2008, Monotoring learning achievement, Federal Government of Nigeria, Abuja.

Fletcher, J., Grimley, M., Greenwood, J. \& Parkhill, F., 2012, 'Motivating and improving attitudes to reading in the final years of primary schooling in five New Zealand schools', Literacy 46(1), 3-15.

Ford, M.E., 1992, Motivating humans, Sage, Newbury Park, CA.

Gambrell, L.B., 2011, 'Seven rules of engagement: What's most to know about motivation to read', The Reading Teacher 65(3), 172-178. http://dx.doi. org/10.1002/TRTR.01024

Gambrell, L.B., Hughes, E.M., Calvert, L., Malloy, J.A. \& Igo, B., 2011, 'Authentic Reading, writing and discussion: An exploratory study of a penpal project', Th Elementary School Journal 112(2), 234-258. http://dx.doi.org/10.1086/661523

Gomrell, L.B., Palmer, B.M., Codling, R.M. \& Mazzoni, S.A., 1996, 'Assessing motivation to read', The Reading Teacher 491(7), 518-533.

Guthrie, J.T., 1996, 'Educational contexts for engagement in literacy', The Reading Teacher 49, 432-445.

International Reading Association, 2000, 'Excellent reading teachers: A position statement of the International Reading Association', Newark, DE.

Kleuseus, J.P. \& Griffith, P.L., 1996, 'Interactive storybook reading for at-risk learners', Reading Teacher 49, 552-560.

Lamont, H.M., 2007, Media, learning, and sites of possibility (New literacies and digital epistemologies), Peter Lang, New York.

Lynch-Brown, C.G. \& Tomlinson, C.M., 2010, Teaching new literacies in grade 4-6 resources for 21st-century classrooms, Guildford, New York.

Madden, L., 1988, 'Improving reading attitudes of poor readers through cooperative reading', The Reading Teacher 42, 194-199.

Makinde, S.O., 2003, 'Problems of reading efficiency in Yoruba', Educational Perspectives 6(1), 74-83.

Mantzicopoulos, P. \& Patrick, H., 2010, 'The seesaw is a machine that goes up and down, young children's narrative responses to science related informational text', Early Education and Development 21(3), 412-444. http://dx.doi. org/10.1080/10409281003701994

McKenna, M.C. \& Kear, D.T., 1990, 'Measuring attitude toward reading: A new tool for teachers', The Reading Teacher 43, 626-639. http://dx.doi.org/10.1598/RT.43.8.3

McLaughlin, M. 2012, 'Reading comprehension: what every teacher needs to know', The Reading Teacher 65, 432-440. http://dx.doi.org/10.1002/TRTR.01064

Mesthrie, R., 2009, 'Assumptions and Aspirations regarding African Languages in South African Higher Education: A sociolinguistics appraisal', in B. Brock-Utne \& S Ingse (eds.), Languages and Education in Africa, Symposium Books, Bristol.
Morrow, L.M., 1988, 'Young children responses to one-to-one story reading in the school setting', Reading Research Quarterly 23, 89-107. http://dx.doi. the school setting',
org $/ 10.2307 / 747906$

Morrow, L.M., 1993, Literacy development in the early years: Helping children read and write, 2 nd edn., Allyn \& Bacon, Boston.

Okebukola, F.O., 1999, 'Read Aloud: An innovation approach to science teaching in difficult circumstances', Proceedings of Ajumogobia Memorial Conference in
Commemoration of the 4Oth Anniversary of STAN, Kano, Nigeria, 1999, pp. 337-340. Commemoration of the 40th Anniversary of STAN, Kano, Nigeria, 1999, pp. 337-340.
kebukola, F.O., 2005, 'Towards an improved reading culture among Nigerian students', Educational Issues 2(1), 54-64.

Okebukola, F.O., 2007, 'A clinical assessment of students' motivation to read', The African Symposium 7(II), 133-141.

Okebukola, F.O., 2008, 'Implementation of the language policy: Beyond rhetoric to empiricism', Journal of Nigerian Languages and Culture II(1), 45-54.

Okebukola, F.O., 2012, 'The views of Nigerian mothers in public and private primary schools on the teaching of early literacy in English', Literacy 46(3), 94-100. http:// dx.doi.org/10.1111/j.1741-4369.2011.00605.x

Okebukola, F.O. \& Apari, W.J., 2012, 'A comparative study of the performance of emergent readers in public and private schools', in P. Anyanwu \& I. Obuasi (eds.), Issues in language and Human, pp. 333-346, SAN Press, Enugu.

Okebukola, F.O., \& Onafowokan, B.A.O., 2003, 'Preparation for scientifically literate students: PQRST to the rescue', Educational Perspective 6(2), 1-10.

Okebukola, F.O. \& Owolabi, T., 2007, 'The efficacy of Question-Answer-Relationships (QAR) on students achievement and conceptual change in science', The International Journal of Learning 14(5), 173-178.

Okebukola, F.O. \& Owolabi, T., 2008, 'Teaching with analogies: The meeting point between science and language', The International Journal of Learning 15(4), 147-150.

Okebukola, P.A., Owolabi, O.L. \& Okebukola, F.O., 2013, 'Mother Tongue as Default Language of Instruction in Lower Primary Science Classes: Tension Between Policy Prescription and Practice in Nigeria', Journal of Research in Science Teaching 50(1) 62-81. http://dx.doi.org/10.1002/tea.21070

Oldfather, P., 1993, 'What students say about motivating experiences in a whole language classroom', The Reading Teacher 46(8), 672-681.

Onukaogu, C.E., 2001, 'Teacher effectiveness as a factor in the reading empowerment of the nursery and elementary school African child', in S. Monokas (ed.), Proceedings of the 1st Pan African reading for all conference, Jos, August 2001, pp. 181-192.

Onukaogu, C.E., 2006, 'International reports on literacy research in Africa', Reading Research Quarterly 41(3), 3.

Owolabi, T., 2006, An Evaluation of the Implementation of the Senior Secondary School Physics Curriculum in Nigeria, PhD thesis, University of Lagos, Lagos.

Owolabi, T. \& Okebukola, F.O., 2009, 'Improving the reading ability of science students through study groups and multiple intelligences', US - China Education review 6(12), 38-43

Palinscar, A.S. \& Ransom, K., 1988, 'From the mystery spot to the thoughtful spot. The instruction of metacognitive strategies', The Reading Teacher 41, 784-789.

Rapley, T., 2007, 'Interviews', in C. Scale, G. Gobo, J. Gubrium \& D. Silverman (eds.), Qualitative research practice, pp. 15-33, Sage, Los Angeles.

Rugemalira, J.M., 2007, 'The communication skills unit and the language problem of the University of Dar es salam', in M. Rubagunya (ed.), Languages in Education in Africa: A Tanzanian perspective, pp. 105-122, Multilingual matters 57, Clevedon, UK.

Ryan, P., 2012, 'Junior reading champions: storytellers as role models for reading', English four to eleven 44, 7-11.

Simmons, D.C. \& Kame'enui, E.J., 1998, What reading research tells us about children with diverse learning needs: Bases and basics, Lawrence Erlbaum Associates, Mahwah, NJ.

Smolkin, L.B. \& Donovan, C.A., 2002, “'Oh excellent, excellent question". Developmental differences and comprehension acquisition', in C.C. Block \& M.
Pressley (eds.), Comprehension instruction; Research-based best practices, pp. Pressley (eds.), Comprehensio
140-157, Guildford, New York.

Smith, P.L., 1988, 'Read - Think - Aloud protocols: A new data source for formative evaluation', Performance Improvement Quarterly 1(2), 13-22. http://dx.doi. org/10.1111/j.1937-8327.1988.tb00011.x

Strauss, R.P. \& Sawyer, E.A., 1986, 'Some new evidence on teacher and student competences', Economics of Education Review 5(1), 41-48. http://dx.doi. org/10.1016/0272-7757(86)90161-5

Talanquer, V., Tomanek, D. \& Novodvorsky, I., 2013, 'Assessing students' understanding of inquiry: What do prospective science teachers notice?', Journal of Research in of inquiry: What do prospective science teachers notice?', Journal of R
Science Teaching 50(2), 189-208. http://dx.doi.org/10.1002/tea.21074

Torahi, C., 2000, 'I read it but I don't get it'. Comprehension strategies for adolescent readers, Stenhouse Publishers, New York.

Vygotsky, L.S., 1978, Mind in society. The development of higher psychological processes, Harvard University Press, Cambridge, MA.

Warwick, B.E., 1999, 'Lifting literacy levels with local research', in S. Monoka (ed.), Proceedings of the 1st Pan African Reading in All Conference, Pretoria, 5-9 August, Proceedings
pp. 31-38.

West African Examination Council (WAEC), 2004, Post Examination Questions and Answers, Yaba, Lagos.

West African Examination Council (WAEC), 2010, Chef Examines Reports, Yaba, Lagos.

Yopp, R.H. \& Yopp, H.K., 2012, 'Informational text as read-aloud of school and home', Journal of Literacy Research 38(1), 37-51. http://dx.doi.org/10.1207/ s15548430jlr3801_2

Yore, L.H., Hildebrand, B., Osborne, J., Treagust, D. \& Wallace, C., 2004, 'New directions in language and science education research', Reading Research Quarterly 39(3), 347-352.

Appendix starts on the next page $\rightarrow$ 


\section{Appendix A}

\section{Frequency of activities for promoting reading} interest

This questionnaire (by the Department of Language, Arts and Social Science Education, Lagos State University, Nigeria) is designed to look into the frequency of use of activities for promoting reading interest. Please endeavour to answer all the questions as truthfully as possible. Information provided will be for the purpose of research. Your responses will be given the confidentiality deserved (see Table 1).
TABLE 1: Please indicate the frequency of your use of the following activities in your reading classroom.

\begin{tabular}{|c|c|c|c|c|c|}
\hline Number & Activity & Very often & Often & Rarely & Never \\
\hline 1. & Reading aloud to children & & & & \\
\hline 2. & Guiding children to read & & & & \\
\hline 3. & $\begin{array}{l}\text { Providing time to browse } \\
\text { in the library }\end{array}$ & & & & \\
\hline 4. & $\begin{array}{l}\text { Identifying children's attitude } \\
\text { to reading }\end{array}$ & & & & \\
\hline 5. & Talking about books & & & & \\
\hline 6. & Using questions & & & & \\
\hline 7. & Storytelling & & & & \\
\hline 8. & Reading picture books & & & & \\
\hline 9. & Using technology & & & & \\
\hline 10. & Reading remediation & & & & \\
\hline
\end{tabular}

